\title{
Gaitasun kognitiboen aplikazioa 5G sareen kontrol- eta kudeaketa-mailetan
}

\author{
(Application of cognitive capabilities in control \\ and management planes of $5 \mathrm{G}$ networks)
}

\author{
Bego Blanco*, Jose Oscar Fajardo, Fidel Liberal, Ianire Taboada ${ }^{1}$ \\ ${ }^{1}$ Bilboko Ingeniaritza Eskola \\ (UPV/EHU) \\ * begona.blanco@ehu.eus
}

DOI: $10.1387 /$ ekaia.16366

Onartua: 2016-10-05

Laburpena: Hurrengo belaunaldiko sareen kudeaketak eskakizun erronkariei aurre egin behar izango die goraka ari diren teknologia gaitzaileen aplikazioaren bitartez. Horrelako kudeaketa-egoera konplexuan, adimen artifizialaren erabilpena ziklo kognitibo gisa erreminta ezberdintzaile eta ahaltsua bilaka daiteke sistemaren errendimendu orokorra hobetzeko. Lan honek cloudean oinarritutako maila anitzeko ziklo kognitiboa aurkezten du, 5G arkitekturaren kontrol- eta kudeaketa-atazak bermatzeko. Eredu berriztatzaile honek eskema kognitibo zentralizatu eta banatuak konbinatzen ditu modulu erabakitzaileetan sare-arkitekturaren maila ezberdinetan, ertzaren eta cloud ingurunearen arteko elkarreragina sustatzeko.

Hitz gakoak: 5G, ziklo kognitiboa, efektu glokala, ertz lausotua.

\begin{abstract}
Next generation network management is envisioned to address new challenging requirements through the application of emerging enabling technologies. In such a complex management scenario, the use of artificial intelligence in the form of cognitive cycles can become a powerful and differentiating tool to enhance system overall performance. This work presents a cloud-based multi-level cognitive cycle to support control and management tasks of 5G architecture. This innovative model combines both centralised and distributed cognitive schemes at decision-making modules in different levels of the network architecture, fostering the interaction between the edge and the cloud environment.
\end{abstract}

Keywords: 5G, cognitive cycle, glocal, blurring edge. 


\section{SARRERA}

5G sare-arkitekturaren diseinu-paradigma berria aurreko belaunaldiko 4G arkitekturatik neurri handian aldentzen da irrati-interfazean ez ezik, baita sare-kudeaketa moldagarrian ere. $4 \mathrm{G}$ sistemen ezaugarri nagusietako bat sare-mailako datu-plano eta kontrol-planoen akoplamendua da; akoplamendu horrek eta banatuta dagoen zerbitzu planoak elkarri eragiten diote. 5G sareak, aldiz, datu- eta kontrol-mailak banatzen ditu: zerbitzu-kudeaketaren osagai batzuk kontrol-mailan integratzen ditu, zerbitzu-instantziak datu-mailan kokatzen diren bitartean .

Desakoplamendu hori hiru teknologiatan oinarritzen da: sarearen softwarizazioa, birtualizazioa eta cloud konputazioa. Teknologia gaitzaile horiek batzean, 5G sareen kudeaketa/kontrol maila orokorrean hiru azpimaila defini daitezke: i) zerbitzuen konfigurazioa kudeatzekoa, ii) zerbitzu horien bizi-zikloa kontrolatzekoa eta iii) hardware baliabideen banaketa antolatzekoa. Honela, bai datu- eta kontrol- mailen banaketa logikoa, bai banaketa logikoa lortzen da. Egoera konplexu honetan, ziklo kognitiboek kudeatzaile ezberdinen erabaki-prozesuan lagundu dezakete azpimaila bakoitzeko baliabideak optimizatzen.

Ziklo kognitiboek inguruneko jakintza gehitzen diete sare-kudeaketaren ohiko atazei. Horrela, sistema-kudeatzaileek sarearen egoera identifikatu eta etorkizuneko egoerak aurreikusten dituzte. Gainera, teknika horiek iraganeko esperientziatik ikasteko gaitasuna ere ematen dute. Ondorioz, adimen artifizialaren aplikazioak sarearen etengabeko aldaketetara eta erabiltzaileen eskakizunetara hobeto moldatzeko aukera ematen du.

Lan honek cloud teknologian oinarritutako maila anitzeko ziklo kognitibo baten aplikazioa proposatzen du 5G sareen kontrol- eta kudeaketamailen operazioa sustatzeko. Hurrengo atalak 5G sarearen arkitektura azaltzen du, eta ondoren, 3 . atalean, sare kognitiboen oinarriak aurkezten dira. Laugarren atalak ziklo kognitiboak 5G sareen kontrol- eta kudeaketa-mailan erabiltzeko soluzio bat proposatzen du. Amaitzeko, azkenengo atalak, 5.ak, ondorio garrantzitsuenak laburbiltzen ditu.

\section{5G ARKITEKTURA}

Etorkizuneko 5G sareek erronka argiak dituzte jadanik: inoizko trafiko-hazkunderik handienaren eskakizunei era jasangarrian aurre egitea eta hainbat egoeratan ertzetik ertzerako etendurarik gabeko erabiltzaile-esperientzia eskaintzea, datu-abiadura ultra-altuarekin, atzerapen ultra-baxuarekin eta konexio masiboekin. Eskakizun horien arabera, 1. irudiak maila altuko 5G sare-arkitektura erakusten du [1]. 
Sarreran aipatu den bezala, 5G sistemen ezaugarri berritzaile bat, aurreko arkitekturekin konparatuta, datu- eta kontrol-mailen bereizketa da [2]. Sare-elementuen hardware- eta software-funtzioen desakoplamendua bai logikoki, bai fisikoki gauzatzen da hurrengo helburuekin: hedapeneta eguneratze-prozesuen koste eraginkorrak, eskaeraren araberako denbora errealean egin daitekeen sare-konfigurazio eta optimizazio automatikoa, kostu-eraginkortasuna eta sare-baliabideen birkokapena. 5G sistemek sarekontrolaren logikaren deslotura eta bere zentralizazioa maila altuago baten sare-egoeraren erabateko ikuspegia eskaintzen dute. Horrela, Sare eta Zerbitzu Orkestratzailea sare-zerbitzuen bizi-zikloa (abiatzea, mantentzea eta amaiera barne) konfiguratu eta kudeatzeko gai da, datu-maila sare-zerbitzuen kokapenaz arduratzen da eta.

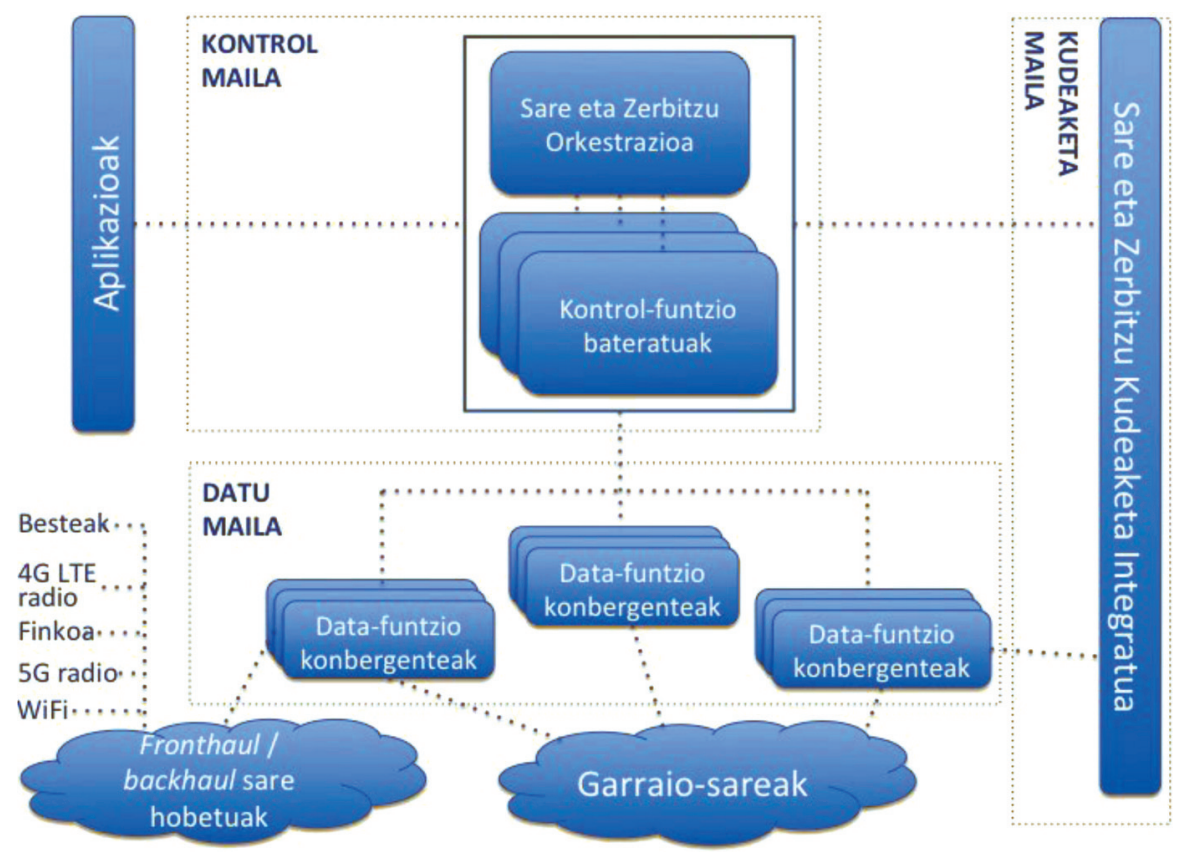

1. irudia. 5G maila altuko sare-arkitektura.

Datu eta kontrol/kudeaketa mailen bereizketa fisikoa lortzeko, MEC teknologia erabiltzen da. MEC teknologiak informazio-teknologiak eta cloud konputazioaren gaitasunak eskaintzen ditu irrati bidezko sarbide-sarean azken erabiltzailetik hurbil [3]. Normalean, kalkulu-zentroetan sortzen diren datu-fluxu guztiak sare mugikor nagusira bideratzen dira, gero berriro oinarri-estazio batera jaisteko eta edukia gailu mugikorretara bidaltzeko. MEC teknologiarekin, cloud zerbitzariek jatorriz kalkulu-zentroetan 
egikaritzen ziren hainbat atazaren ardura hartzen dute, eta horrela datu-fluxuak sare nagusiaren bitartez bideratzeko derrigortasuna kentzen da. Modu honetan, sarbide-sareko ertzak bai latentzia baxuko eta banda-zabalera altuko zerbitzu-ingurunea, bai irrati-sareko informaziorako denbora errealeko sarbidea eskaintzen du. Azkeneko hori gaineko mailek erabil dezakete ingurunea ezagutzen duten zerbitzuak emateko.

Amaitzeko, NFV egituraren integrazioak beste aurrerapauso bat ematen du sistema errendimenduaren optimizioaren alde. 2. irudiak European Telecommunications Standards Institute-k proposatutako NFV arkitektura erakusten du [4].

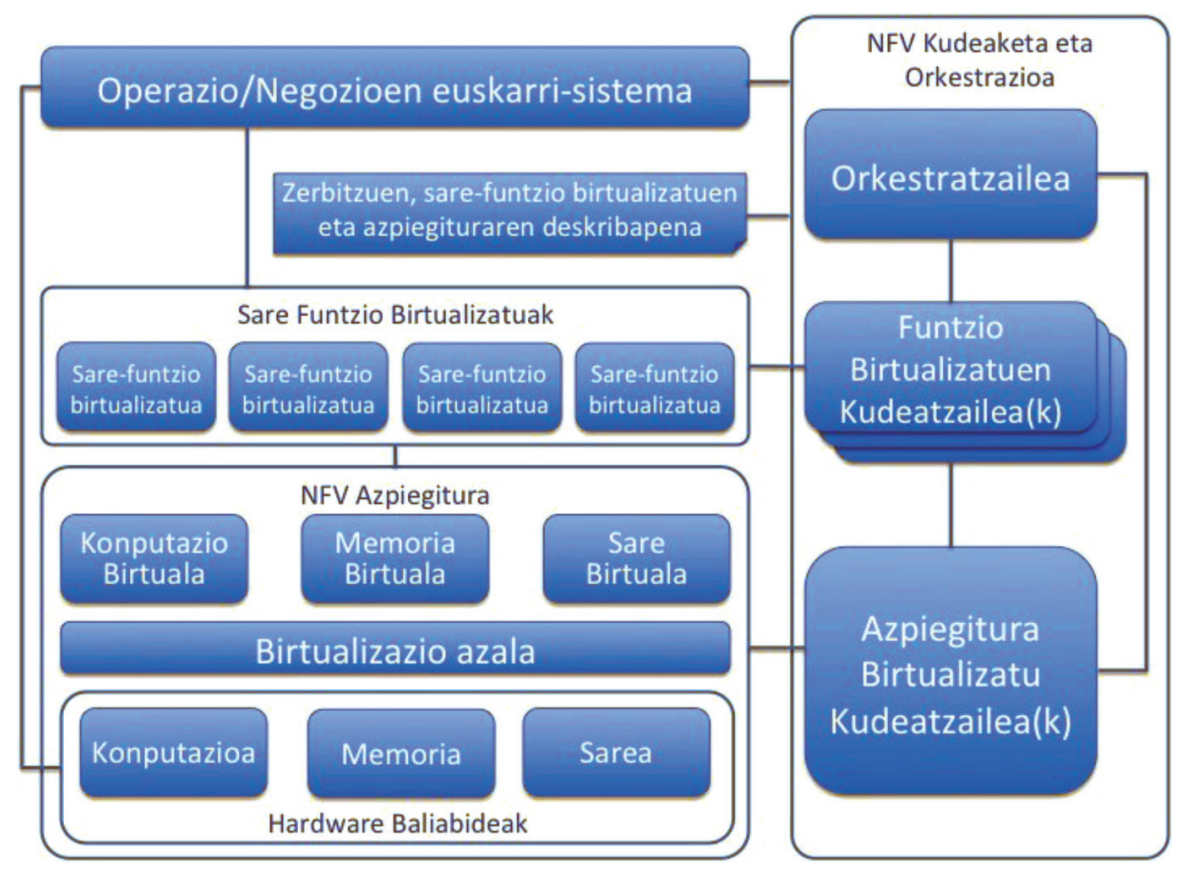

2. irudia. ETSI NFV sare-egitura.

NFV kontzeptuak sare-funtzioak softwarean bakarrik oinarritutakoak izatea eta NFV azpiegituraren gainean egikaritzen diren entitate bezala inplementatzea ezartzen du. NFV MANOren (NFV MANagement and Orchestration) parte izanik, NFV Orkestratzaileak (NFVO) sare-zerbitzuen eransketa kudeatzen du, VNFak kateatuz eta baliabideak banatuz. VNF Kudeatzaileak (VNF Manager-VNFM) VNF instantzien bizi-zikloaren kudeaketa ikuskatu eta NFVIren eta (E)NMSren (Element/Network Management System) arteko konfigurazio- eta informazio-prozesua koordinatzen 
du. Azkenez, Azpiegitura Kudeatzaile Birtualizatuak (Virtualized Infrastructure Manager, VIM) NFVIren konputazio-, memoria- eta sare-baliabideak kontrolatu eta kudeatzen ditu.

Ondorengo atalak ziklo kognitiboei buruzko literatura aztertzen du, sare-zerbitzuen eskaintzan parte hartzen duten hainbat erabaki-hartzaileren barruan adimena sartzeko helburuarekin.

\section{SARE KOGNITIBOAK}

Sare kognitiboen filosofia entzutetsua den Irrati Kognitibo Ereduaren (Cognitive Radio Model) orokortzea da [5]. Kontzeptu hori haririk gabeko sareen espektro elektromagnetikoaren erabilpen eraginkorragoa egiteko proposatzen da. Ideia nagusia transmisio-parametroak aldatzea da, behatutako barneko eta kanpoko faktoreen arabera. Irrati kognitiboa, softwarearen bitartez definitutako irratiaren gainean eraikitakoa, haririk gabeko komunikazio-sistema adimentsua bezala deskribatzen da. Teknologia horrek ezagutzen duen inguruneko egoera horretatik ikasten du eta hainbat adierazleren aldakuntza estatistikoetara moldatzen da.

Sare kognitiboak [6] irrati kognitiboaren printzipioak komunikazioaren erreferentzia-ereduaren beste mailetara estrapolatzen ditu, gizakiaren parte-hartzea minimizatuz eta sarearen etengabeko egoera-aldaketetara eta erabiltzaileen eskakizunetara moldatuz. Mota horretako sarearen egoera behatu, geroko ekintzak planifikatu, erabaki bat hartu eta era kontsekuentean jarduten duen prozesu kognitiboa da. Helburu horrekin, sare kognitibo batek sarearen kondizioak identifikatu eta geroko egoerak aurreikusten ditu, sarearen egoera dinamikora etengabe moldatzen doa, iraganeko esperientziatik ikasten du eta zerbitzuaren akordioaren arabera erabiltzaile guztien eskakizunak orekatzen ditu [7].

Ezaugarri horiek 3. irudian agertzen diren hiru ziklo kognitiboetan aurki daitezke [8-10]. Hiru ziklo horiek lehenengo fase baten datu gordinak biltzen dituzte, gero informazioa prozesatu egiten dute eta ekintza bat gauzatzea erabakitzen dute. a) adibideko ziklo sinplifikatuan, feedback informazioa fasetik fasera pasatzen da. Horrela zikloaren iterazio bakoitzean aurreko iterazioko emaitzak erabiltzen dira behatutako informazioa prozesatu eta erabakirik egokiena hartzeko. b) adibideko zikloak ikasketa-fase bat gehitzen dio eskemari. Ikasketa-fase horrek beste fase guztietatik feedbacka eskuratzen du gainontzeko prozesuetan erabiltzen diren ereduak eguneratu eta aberasteko. Amaitzeko, c) adibideak politika-modulu bat gehitzen dio zikloaren arkitekturari. Modulu horrek posibleak diren soluzioen planifikazioan eta erabakia hartzeko prozesuan du eragina. Bere helburua kanpoko aldetik estrategien ildoak ezarri ahal izatea da. 


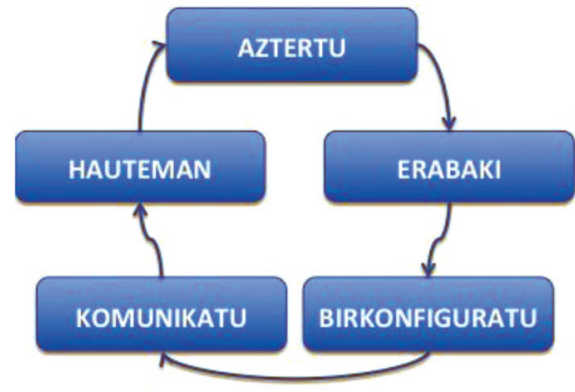

a)

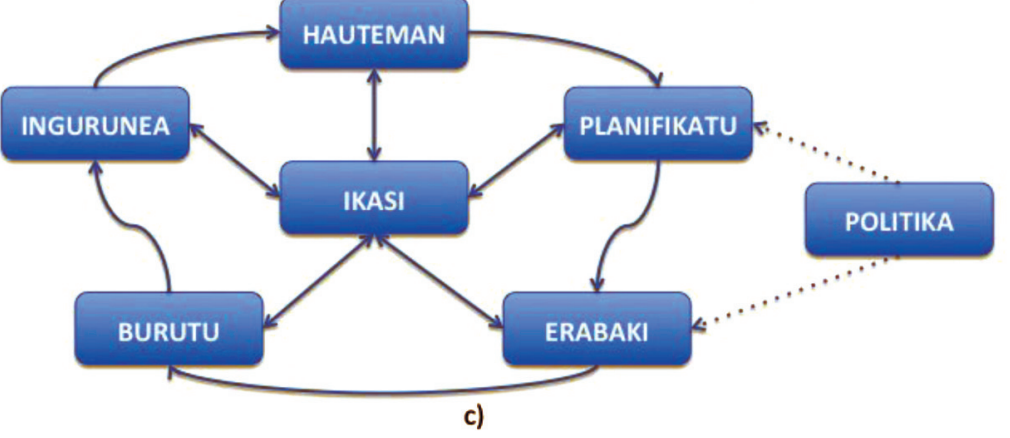

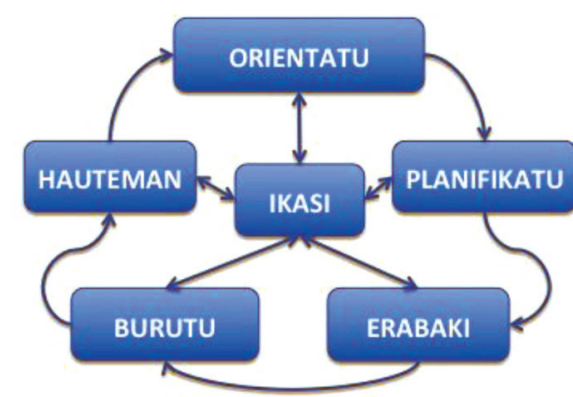

b)

3. irudia. Ziklo kognitiboen adibideak.

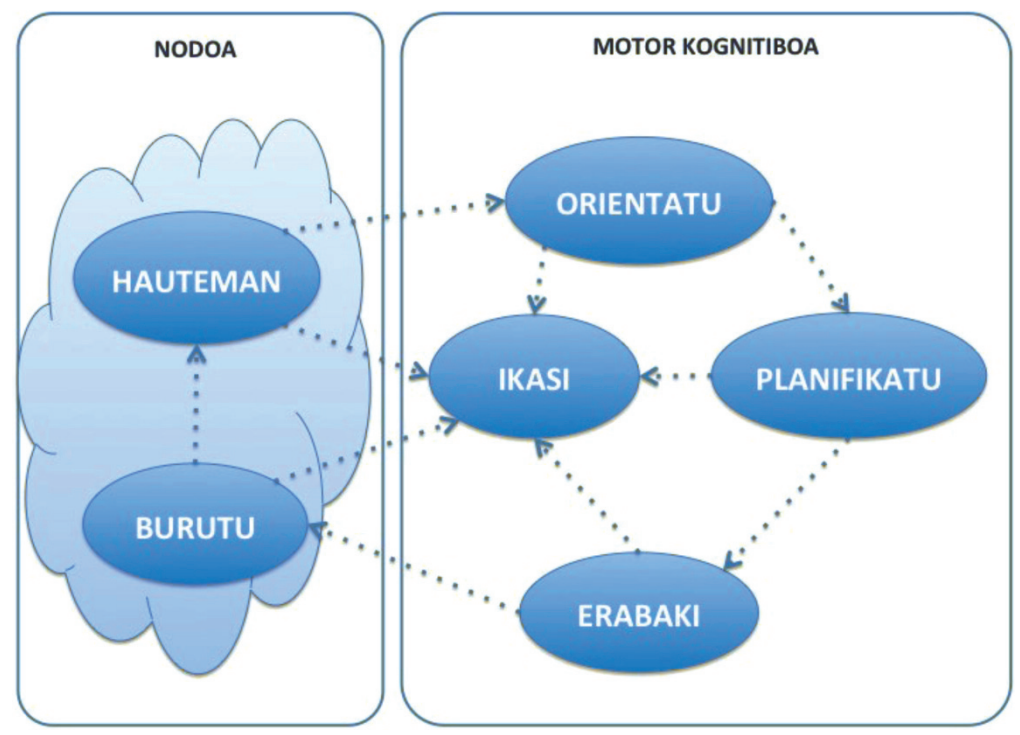

4. irudia. Nodo birkonfiguragarriaren arkitektura. 
Aukeratutako ereduaz gain, behin ziklo kognitiboa eta fase bakoitzean erabiltzen diren teknikak diseinatuta daudela, hainbat modutan inplementa daitezke. Adimen kognitiboa zentralizatua edo banatua izan daiteke diseinuaren eskakizunen arabera. Ziklo kognitibo banatuaren adibide bat Nodo Birkonfiguragarrian [12] aurki daiteke. Eredu horrek bere faseak bi entitatetan bereizten ditu (4. irudia): arrazoiketa-, ikasketa- eta erabaki-adimenak elkartzen dituen motor kognitiboa, eta nodo birkonfiguragarria, behaketan eta ekintzan oinarritzen dena. Nodo birkonfiguragarria software- eta hardware-elementuez osatuta dagoen egitura da. Motor kognitiboak osagaiak lotzen ditu informazio-prozeduraren emaitzen arabera, eta behar bezala alda daiteke.

Behin sare kognitiboen oinarriak ikusita, hurrengo atalak 5G sareko arkitekturan erabakiak hartzen dituzten moduluetan ziklo kognitibo bat aplikatzeko proposamen bat aztertuko du.

\section{ZIKLO KOGNITIBOEN APLIKAZIOA 5G SAREEN KONTROL ETA KUDEAKETA MAILETAN}

Analisten arabera, bosgarren belaunaldiko haririk gabeko teknologia 2020. urterako komertzializatuta egotea espero da. Horren ondorioz, 5G sareen erabilera-kasuek erabateko eragina izango dute bizitzako hainbat esparrutan, hezkuntza eta medikuntzatik hasita garraio eta finantzetaraino. Baina telekomunikazio-teknologia berriek industria horiek guztiak teknikoki aurrera bultzatuko duten bitartean, sare-operadoreek teknologia komertzialki bideragarria egitea izango dute erronkatzat.

Sareak etorkizunean izango dituen eskakizun hain handiak izango direnez, ezinbestekoa bilakatu da erabilgarriak diren baliabideak modu eraginkorrean banatzea. Testuinguru horretan, adimen artifizialeko teknikak onuragarriak bilaka daitezke $5 \mathrm{G}$ arkitekturaren diseinuarentzat. Aurreko atalean deskribatutako ziklo kognitiboak 5G arkitekturaren erabaki-osagaietara aplika daitezke bai oinarri-estazioetako baliabideen erabilera eraginkorra eta jasangarria sustatzeko, bai cloudean gauzatzen diren atazak optimizatu eta kudeatzeko.

Gure proposamena 5G arkitekturaren bi kontzeptutan ardazten da: sare-elementuen birtualizazioa eta cloud konputazioa. Sarreran aurreratu den bezala, 5G sareen kudeaketa/kontrol maila hiru azpimailetan zatitu daiteke NFV sare-egiturari jarraituz. Goiko azpimaila baten, Sare Kudeakea Sistemak 5G zerbitzuen konfigurazioa zuzentzen du Sare Orkestratzailearen bitartez. Urrats bat beherago, birtualizazio-mailan, Funtzio Birtualizatuen Kudeatzaile zentralizatua sare-zerbitzuen bizi-zikloaz arduratzen da. Amaitzeko, birtualizatu den azpiegitura-mailan, Azpiegitura Birtualizatuaren Kudeatzaileak hardware-baliabideen banaketa antolatzen du. 


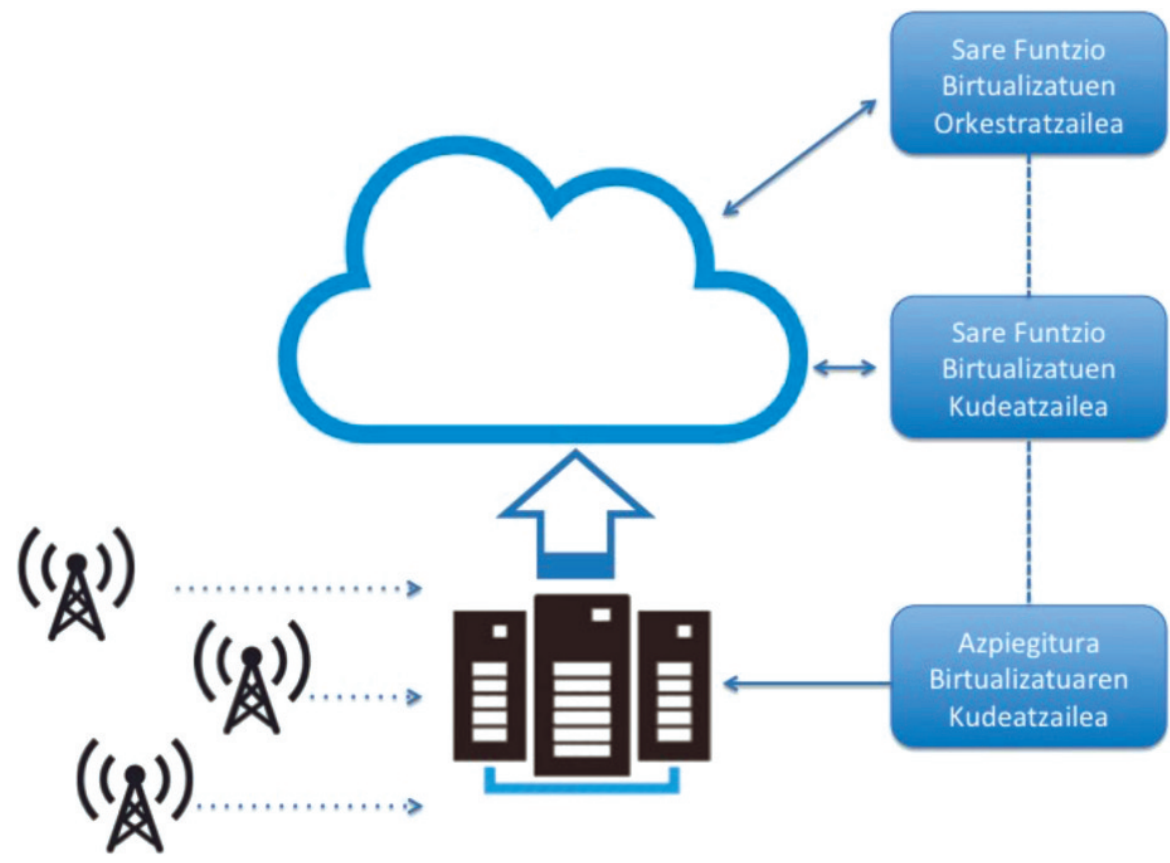

5. irudia. Cloud teknologiaren aplikazioa 5G sare-arkitekturara.

Banaketa horrek datu eta kontrol/kudeaketa mailen desakoplamendu logikoa egiten du posible. Baina cloud konputazioaren bitartez, desakoplamendu fisikoa ere lor daiteke. 5. irudiak erakusten duen moduan, cloud teknologiak NFV arkitekturako kudeaketa- eta orkestrazio-moduluak espazialki banatzea ahalbidetzen du.

Alde batetik, birtualizazio-teknologiarekin erlazionatuta dauden azpimaila bakoitzeko kudeatzaileak bere mende dauden baliabideen antolaketa bere kabuz egin dezake. Horretarako, ziklo kognitibo bateratu bat erabil daiteke, modulu bakoitzak inguruko datu lokalak jaso eta bertan prozesatzen dira erabaki egokienak hartzeko.

Bestalde, cloud teknologiaren filosofia eredu kognitibo banatu batera hobeto moldatzen da. Horrelako ereduek oinarri-estazioan sortutako operazio lokalaren informazioa behatu eta biltzen dute geroago era heuristikoan prozesatu eta jakintza berria ateratzeko. Emaitza bezala, erabaki-erregela berriak sortu eta erabaki-osagaietan gordetzen dira hurrengo iterazioetan erabiltzeko. Funtzionamendu-modu horrek MEC arkitekturaren ezaugarri bereizgarriak indartzen ditu, hau da, latentzia baxua, ingurune-jakintza, datu-zirkulazio minimizatua eta sare-pilaketa murriztua. 
Nodo Birkonfiguragarria bezalako eredu kognitibo banatuak sare-operazioari buruzko informazio guztia cloud zerbitzarietan bil dezake konputazio- eta memoria-baliabide altuagoak aprobetxatzeko. Puntu honetan, oso datu gordin kopuru handiak prozesatzeko, Big Data teknikak erabilgarriak izan daitezke. Horrela, gero sare-ertzera bidaliko diren erabaki-erregela optimizatuak lor daitezke.

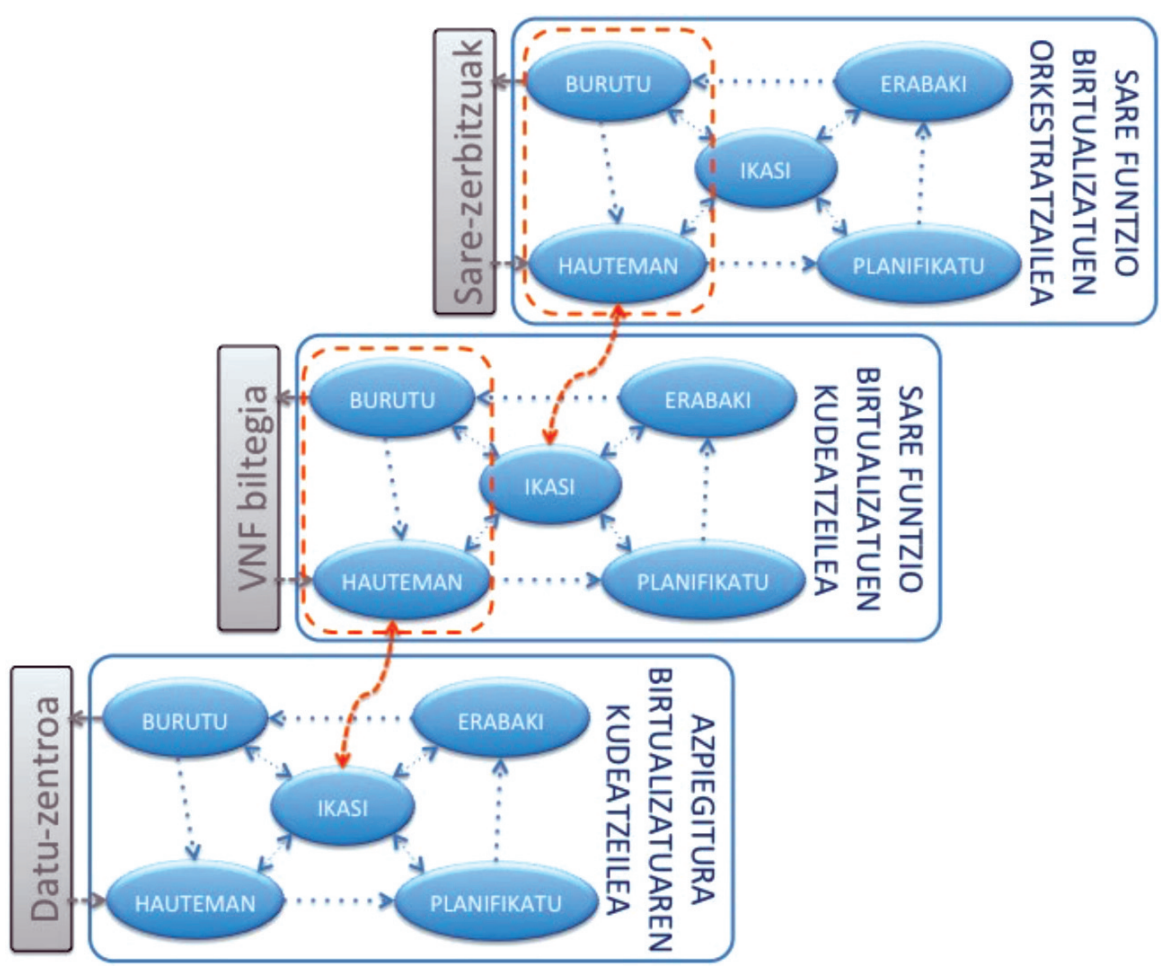

6. irudia. Cloudean oinarritutako maila anitzeko ziklo kognitiboa.

Gogoeta horien ondorioz, 6. irudian eredu banatu eta zentralizatu baten konbinazioa den cloudean oinarritutako maila anitzeko ziklo kognitiboa proposatzen dugu. Azpiko mailan, Azpiegitura Birtualizatuaren Kudeatzaileak 3. atalean ikusitako ereduen bertsio bat aplikatzen du oinarri-estazioko baliabide fisikoen antolaketa bermatzeko. Proposatzen dugun zikloak lau fase sekuentzial ditu (Hauteman-Planifikatu-Erabaki-Burutu) eta Ikasketafase zentrala aurreko lau faseekin komunikatzen da.

Hautemate-fasea elikatzen duten adierazleak estazio bakoitzean sortzen direnak dira. Egoera honetan, planifikazio faseak VNFak baliabide erabilgarrietan kokatu eta banatzeko aukerak aztertzen ditu, gero operazio-ekin- 
tza baten amaituko duen erabaki erregela bat aplikatzeko. Pauso horiek guztiek feedbacka ematen diote emaitza era heuristikoan aztertzen duen ikasketa-moduluari, eta honek erabaki-erregela hobetuak erauzten ditu. Horrela, prozesu osoa oinarri-estazioan exekutatzen da, logika guztia ertzean mantenduz.

Ondorengo mailan, Sare Funtzio Birtualizatuen Kudeatzaileak Nodo Birkonfiguragarriaren ereduaren bertsio bat inplementatzen du. Bertsio horrek ziklo kognitibo sinplifikatu bera hartzen du oinarritzat Motor Kognitiboa osatzeko. Ondoren, Nodo Birkonfiguragarriak bere behaketa-fasean Azpiegitura Birtualizatuaren Kudeatzailearen ikasketa-fasetik hartutako eta cloudaren bitartez igotako informazioa gehitzen du. Bigarren ziklo kognitibo horrek Funtzio Birtualizatuaren Kudeatzailearen atazak bermatzen ditu sare-funtzioa osatzen duten kateak konposatu ahal izateko, eta VNFen hedatzea kudeatzen du. Azpimarratzekoa da modulu horrek hainbat oinarri-estazio batera kudea dezakeela, horrek dakarren prozesatu beharreko laginen gehitzearekin. Ondorioz, datu kopuru handiak Big Data prozesamendu-teknikak behar ditzake eta horiek cloud zerbitzarietan inplementatuko lirateke.

Proposatzen den Nodo Birkonfiguragarriaren bariazioak ondorengoa egiten du posible: Azpiegitura Birtualizatuen Kudeatzailean dagoen ziklo kognitiboak era askean jardun dezake modu bateratu baten, baina bere operazioa beharrezkoa denean, eguneratua izan daiteke goiko mailetako jakintza baliagarria gehituz. Ondorioz, ertz lausotuaren efektua lortzen da: maila baxuko ziklo kognitibo banatuak MEC printzipioa indartzen du, erabakilogika erabiltzailearengandik hurbil mantenduz. Baina, era berean, Nodo Birkonfiguragarriaren ereduaren moldaketaren operazio-informazio baliagarria cloud zerbitzarietara igotzen du. Horrela, bi zentzuko efektu glokala lortzen da: lehenbizi, Azpiegitura Birtualizatuaren Kudeatzaile barruan inplementatutako ziklo kognitiboak informazio lokalarekin soilik funtziona dezake, baina sortutako jakintzak Sare Funtzio Birtualizatuen Kudeatzailean dagoen motor kognitiboa elikatzen du, sarearen errendimenduaren hobekuntza globala lortuz. Motorraren jakintza-emaitzak, aldiz, azpiko mailako ikasketa-eskema ere birkonfiguratzen du, geroko laginentzat erabaki zorrotzagoak eskainiz.

Azkenez, egitura hori gorantz errepikatzen da kudeaketa-mailan. Hemen, Motor Kognitiboa Orkestratzailean inplementatzen da, operadore fisiko eta birtualei zerbitzua ematen dien sare-xerrak (network slice, ingelesez) kudeatzeko. Arrazoibide berari jarraituz, azpiko mailekiko elkarreragina ere bi zentzukoa da. Sare Funtzio Birtualizatuen Kudeatzailean inplementatzen den ziklo kognitiboaren ikasketa-moduluak Nodo Birkonfiguragarri bezala jokatzen du, beste lagin iturri bat bihurtuz ikasketa-prozesua elikatzeko. Aldi berean, jakintza eguneraketak jasotzen ditu bere operazioa maila altuagoko erabaki-erregelekin aberastuz. Ondorioz, sare-xerren 
jarduera findu egiten da, sare-operadoreen eskakizunak errendimendu optimizatu baterako NFV kudeaketa-egoeraren osagarri izanez.

\section{ONDORIOAK}

Haririk gabeko sareak gaitasun kognitiboez hornitzeak bere funtzionamenduan sortzen den kudeaketa- eta kontrol-informazioa ustiatzea posible egiten du. Horrela, egoera lokalari buruzko ezagutza ondorioztatu eta ustia daiteke etekin globala handitzeko. Lan honek ziklo kognitibo zentralizatu eta banatuen erabilera konbinatua aztertzen du $5 \mathrm{G}$ sareen hainbat mailatan parte hartuz: datu-maila integratua, kontrol-maila bateratua eta cross-layer kudeaketa. Testuingurua ezagutzen duen eskema kognitibo honek erabakiak hartzen dituzten moduluetan jarduten du, monitorizatzen duen ingurunearen araberako okerrak aurreikusteko, egikaritze birtualizatua orekatzeko eta zerbitzu mugikorren horniduraren hobekuntza globala lortzeko. Maila anitzeko ziklo kognitiboak sare-ertzaren eta cloud ingurunearen arteko elkarreragina bermatzen du, bi paradigmak banatzen dituen lerroa lausotuz: irrati bidezko eragiketa zentralizatua eta ertzeko zerbitzu mugikorrak.

\section{BIBLIOGRAFIA}

[1] ITU-T. 2015. «FG IMT-2020: Report on Standards Gap Analysis».

[2] NGMN. 2015. «5G White paper».

[3] ETSI. 2014. «Mobile-Edge Computing-Introductory Technical White Paper».

[4] ETSI. 2014. «ETSI GS NFV-MAN 001 v1.1.1: Network Functions Virtualisation (NFV) - Management and Orchestration».

[5] BIGLIERI, E., GOLDSMITH, A.J., GREENSTEIN, L.J., MANDAYAM, N.B., POOR, H.V. 2012. «Principles of Cognitive Radio», Cambridge University Press.

[6] CLARK, D.D., PARTRIDGE, C., RAMMING, J.C., WROCLAWSKI, J.T. 2003. «A knowledgeplane for the internet». In proceedings of Conferenceon Applications, Technologies, Architectures, and Protocols for Computer Communications (SIGCOMM '03), New York, USA.

[7] HAIGH, K. 2011 «AI Technologies for Tactical Edge Networks».In Proceedings of IEEE MobiHoc Workshop on Tactical Mobile Ad Hoc Networking.

[8] MITOLA, J. 1999. «Cognitive Radio for Flexible Mobile Multimedia Communications». In IEEE International Workshop on Mobile Multimedia Communications (Mo- MuC'99), 1:3-10.

[9] STRASSNER, J.,AGOULMINE,N.,LEHTIHET,E. 2006. «FOCALEA Novel Autonomic Networking Architecture». ITSSA J., 3(1): 64-79. 
[10] BALAMURALIDHAR,P.,PRASAD,R. 2008. «A Context Driven Architecture for Cognitive Radio Nodes». Wireless Personal Communications, 45(3): 423-434.

[11] FORTUNA, C., MOHORCIC, M. 2009. «Trends in the development of communication networks: Cognitive networks». Computer Networks, 53(9): 1354-1376.

[12] SUTTON, P., DOYLE, L.E., NOLAN, K.E. 2006. «A Reconfigurable Platform for Cognitive Networks». In Proceedings of IEEE International Conference on Cognitive Radio Oriented Wireless Networks and Communications, 1: $1-5$. 